Aurignacian, pushes westward, and separates these two great provinces. From the Aurignacian and Gravettian centres migrations pour into Central and Eastern Europe along the southern edge of the ice-sheet, and cultures which in their homelands tend to remain distinct and exclusive succeed and influence each other, until at the extreme limit of their journey we get the characteristic French sequence, which for so long was used as a standard for the rest of the world. Meanwhile, along the fringes of the original provinces interpenetration necessarily takes place, and we find the Upper Gravettian filtering along the valleys of the Zagros Arc into southern Kurdistan, while the Aurignacian penetrates northward into the Crimea. Finally, at the close of the Pleistocene, migration on a large scale comes to an end, and numerous local variations spring up all over the Palæolithic world.

Outside all this, meanwhile, lies the still mysterious Far Eastern province, with its mixed flake and blade culture. In its early stages this may conceivably have played a part in the evolution of the Aurignacian proper, and in this connexion it is perhaps significant that Gordon Childe reports the presence of a slit-base bone point at Malta.

The picture which $I$ have outlined is admittedly largely speculative. I am prepared to be accused of domination by a mirage orientale, but to that I would reply that some of my colleagues seem to me at the moment to be unduly influenced by a mirage africain. Only further discovery will make it possible to decide between us.

\title{
Obituary
}

\section{Dr. George Forbes, F.R.S.}

$\mathrm{D}^{\mathrm{n}}$ . GEORGE FORBES, who died at Worthing on October 22 at eighty-seven years of age, was a well-known electrical engineer in the early days of electric lighting and electrical transmission of power. He was a man of great versatility, and in addition to electrical engineering work he did much useful physical research and was also greatly interested in astronomy. He was an intimate friend of the late Sir David Gill, formerly H.M. Astronomer at the Cape of Good Hope.

After taking his degree at Cambridge, Forbes was appointed professor of natural philosophy at Anderson's College, Glasgow, and occupied the chair from 1872 until 1880. One of his chief pieces of physical work was an extensive research on the velocity of light, carried out in conjunction with Dr. T. Young, between 1876 and 1880 and described in the Phil. Trans. Roy. Soc. of 1882 . They used a modified form of Fizeau's method and an are lamp as a source of light, working over a Scotch loch for a distance of about 3-4 miles. The result they obtained was 301,382 kilometres per second, which is rather in excess of the best results of Michelson and others. The chief novelty of their work was that they found a supposed greater velocity for blue light than red by about 1.8 per cent. Astronomical observations give, however, a denial to such a conclusion and it has not been held to be valid. Forbes also took part in astronomical expeditions, and when only twenty. five years of age he conducted a British party to Hawaii to observe a transit of Venus with the object of determining the solar parallax and distance. He wrote an excellent small book in Benn's Sixpenny Library Series on "The Earth, the Sun, and the Moon"

When electric lighting work began in England in the early 'eighties of last century, after the invention of the carbon filament electric lamp by Edison and Swan, Forbes came to London and was adviser or manager of one of the then formed electric manufacturing companies. He made improvements in an arc lamp and invented an electric meter for alternating electric currents. One of his most permanent improvements was the application of hard graphitic carbon as brushes for electric motors. Before that time it was usual to employ brushes of brass or copper gauze or wire; but these caused unnecessary wear of the commutator. Forbes suggested brushes made of graphitic carbon in the same fashion as are lamp carbons, and this was a great improvement and is used almost entirely at the present day.

When the great scheme of utilizing the power of Niagara Falls for production of electric current was under consideration, Forbes was one of those (and also the writer of this notice as well) consulted by the projectors as to the system of generation to be employed. In 1891 there was an electrical exhibition at Frankfort-on-Main, and one of the most interest. ing features was the transmission of power electrically over a distance of 110 miles from Lauffen to Frankfort by means of three-phase alternating electric currents. This transmission comprised the use of 300 h.p. generated at 55 volts and a frequency of 40 cycles. The voltage was raised by transformers to 8,500 volts and reduced again at the receiving end. The success of this performance gave a great impulse to the vaster scheme of utilizing Niagara, and the Cataract Company was formed to carry it out. After taking numerous opinions, it was decided to employ two-phase alternating currents, and generators driven by turbines were constructed of 5,000 h.p. to generate at 5,000 volts for transmission at 11,000 volts to Buffalo and other cities. Forbes went to Niagara to superintend the electrical work. At present, nearly a million horse-power is taken from the Falls.

Forbes travelled extensively, and in 1877 acted as special correspondent of The Times during the RussoTurkish War. $\mathrm{He}$ was the recipient of many 
distinctions for his scientific work. He was elected a fellow of the Royal Society of London in 1887 and received the honorary degree of LL.D. from the University of St. Andrews. He was a Chevalier of the Legion of Honour of France and an honorary member of the Franklin Institute of America.

Forbes invented a range-finder for military work used in the South African War, and a gun-sight for the Navy. He was granted a Civil List Pension in 1931 for his services. Of late years he had not been seen much in scientific society, except for occasional visits to the Athenæum, but in the later years of the nineteenth century he was a well-known member of various British scientific societies and often seen in social and scientific gatherings. He was at one time a vice-president of the Institution of Electrical Engineers. An obituary of him appeared in the Daily Telegraph of October 26 last from which by permission some of the above statements are taken and acknowledgement is here made for the courtesy. J. A. F.

\section{Sir George Hampson, Bt.}

Sir George Hampson, who died on October 15, at Thurnham Court, near Maidstone, at the age of seventy-six years, came of an ancient Oxfordshire family, the baronetcy having been created in 1642; he succeeded to the title on the death of his uncle in 1896. He was born on January 14,1860 , the eldest son of the Rev. W. S. Hampson, rector of Stubton, Lincolnshire. He was educated at Charterhouse and at Exeter College, Oxford, where he graduated.

Already in 1883 Hampson was collecting Lepidoptera, as a side-line to planting tea, in the Nilgiri Hills in southern India, and his serious interest in entomology appears to have been born during the five years which he spent in these surroundings. The latter half of the nineteenth century was a kind of golden age in the history of entomological discovery in India, when Marshall and de Nicéville, Moore, Swinhoe, Bingham, Butler and others were constantly extending and gradually reducing to some sort of order our knowledge of the Indian Lepidoptera. But whereas these workers were principally concerned with the butterflies, Hampson, no doubt largely inspired by their activities, after producing a "Catalogue of the Butterflies of the Nilgiris" (which remained in MS.), turned his attention to the moths, in the study of which he was later to achieve a world-wide and unique reputation.

By 1889, Hampson was busily engaged as a voluntary worker in the Insect Room of the British Museum, both upon the general arrangement of the Heterocera and, more particularly, the Indian moths. In 1891 and 1893 the. Trustees of the Museum published his first considerable works, namely, his accounts of the Heterocera of the Nilgiris and of Ceylon, which formed Parts 7 and 8 of the "Illustrations of Typical Heterocera in the British Museum". The four volumes, and supplements, of the "Moths of India" appeared between 1892 and 1896, forming part of the Fauna of India series issued by the
Government of India; these set the seal upon his reputation and remain still the only comprehensive work on the subject.

Meanwhile Hampson had been offered an appoint. ment as assistant under Dr. Günther in the Department of Zoology in the British Museum. He accepted this post, and took up his duties in January 1895. This placed him in charge of the whole of the collection of moths, and immediately he concentrated his attention almost exclusively upon the production of his truly monumental "Catalogue of the Lepidoptera Phalænæ in the British Museum". Between 1898 and 1923 fifteen volumes were published. This was, in fact, an attempt at a fully documented and illustrated descriptive catalogue of the moths of the world, and manifestly too great a task for any one man to perform. Yet it is amazing how much Hampson achieved, and how much more he had achieved than was ever published, for on his retirement in 1920 he left a great quantity of manuscript, of which the bare bones were issued in 1926 as a single volume entitled "New Genera and Species of Noctuidæ in the British Museum". The catalogue included the Syntomidæ, Arctiidæ, and the major part of the Noctuidæ, that is to say, perhaps one third of the moths which are usually called Macrolepidoptera. Yet during the progress of this work, Hampson found time to publish many valuable and extensive papers dealing with the large and important family of Pyralidæ, notable among which is his account of the Phycitinæ and Galleriinæ (in continuation of Ragonot's work) which formed vol. 8 of the Romanoff "Memoirs".

Times have changed greatly in entomological circles since Hampson took up his task. His working equipment consisted of a hand lens, benzene (for temporarily clearing the wings) and a pair of dividers. It is scarcely a matter of surprise that more recent investigations have brought to light many facts which escaped him. He was always more inclined, too, to concede a far greater range of variation in species than was customary at the time his early volumes appeared, possibly as a reaction to the obviously unjustified hair-splitting of such workers as Butler, Moore and Swinhoe, and in consequence, especially in the "Moths of India", some of his "species" have been shown to be compact of many. There can be few systematists, however, against whom such a charge cannot be levelled.

The present writer remembers well, as a very young man, his first introduction to Hampson. $\mathrm{He}$ had some foreign moths to name, and on asking for help, was firmly but courteously told that "he would find them over there-" a wave of Hampson's arm indicating the entire collection of Heterocera in the Museum. This was very characteristic; but it had some advantages. It enabled the speaker to proceed uninterrupted with his work, and it forced the inquirer to learn something about the moths in such a way that he would remember it. Hampson's methodical industry was amazing, and his "Catalogue" is not only a worthy testimony to it, but also a mine of information that will not be exhausted for many years.
N. D. R. 